\title{
An Interesting Case of Adenocarcinoma: Miliary Metastases
}

\section{IIIginç Bir Adenokanser Olgusu: Milier Metastaz}

Canatan Taşdemir, Yusuf Aydemir

\section{Abstract}

Diffuse miliary lesions in the lungs are mostly observed in tuberculosis, sarcoidosis and pneumoconiosis, while hematogenous metastases of some cancers of the lung may rarely have a miliary appearance. We present here a case of primary lung adenocarcinoma with miliary lesions and diagnosed by bronchoscopy.

Key words: Miliary lung lesions, adenocarcinoma, hematogen metastasis.

\section{Özet}

Akciğerlerde yaygın milier görünüm daha çok tüberküloz, sarkoidoz ve pnömokonyozlarda gözlenir. Bazı kanserlerin akciğere hematojen metastazları da, nadiren milier görünüm yapabilir. Biz milier dağılım gösteren ve bronkoskopi ile tanı koyduğumuz bir primer akciğer adenokarsinomu olgusunu sunduk.

Anahtar Sözcükler: Milier akciğer lezyonları, adenokanser, hematojen metastaz.
Department of Chest Diseases, Sakarya University Faculty of Medicine, Sakarya, Turkey
Sakarya Üniversitesi Tıp Fakültesi Göğüs Hastalıkları Anabilim Dalı, Sakarya

Submitted (Başvuru tarihi): 06.07.2021 Accepted (Kabul tarihi): 06.09.2021

Correspondence (Iletişim): Canatan Taşdemir, Department of Chest Diseases, Sakarya University Faculty of Medicine, Sakarya, Turkey

e-mail: canatan64@hotmail.com

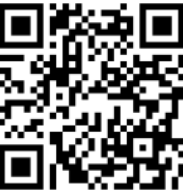


Multiple, millimeter-sized, discrete, usually well-defined and widespread densities are referred to as miliary lesions in the lungs. Although a diffuse miliary appearance primarily suggests miliary tuberculosis, it can often be observed in pneumoconiosis and sarcoidosis. In rare cases, miliary lesions can also be observed in the hematogenous spread of carcinomas, and mostly in the form of thyroid and renal cancers and lung metastases of melanomas. The miliary distribution of lung cancers is very rare (1-4). Lung adenocarcinomas are the most common histological subtype of lung cancer, accounting for around half of all lung cancers. Some $60-70 \%$ of adenocancers are located peripherally, and appear as nodules, masses and infiltrations, although adenocarcinomas can also be seen as diffuse or localized parenchymal infiltrates (1-4). We describe here a case of lung adenocarcinoma presenting with diffuse miliary metastasis due to its rarity and unusual radiological appearance.

\section{CASE}

A 70-year-old male patient applied to our center with complaints of cough for six months, weakness for the last one month, weight loss of 3-4 kg, and bloody sputum for the last three days. The patient's left hilum was enlarged, and bilateral diffuse miliary lesions were observed on chest $X$-ray, and the patient was subsequently admitted to our service.

The patient was a farmer with a 75 pack-year smoking history who was still smoking. Upon physical examination: fever: $36.5{ }^{\circ} \mathrm{C}$, blood pressure: 120/70 mmHg, Pulse Rate: $70 / \mathrm{min}$ and respiratory rate: $22 / \mathrm{min}$ were recorded. In a respiratory system examination, bilateral mild coarsening was identified in the respiratory sounds. Complete blood count and biochemical tests were normal, and the erythrocyte sedimentation rate was $23 \mathrm{~mm} / \mathrm{h}$. A Posteroanterior Chest $X$-ray revealed left hilar fullness and bilateral diffuse miliary lesions (Figure 1).

In a computed tomography of the thorax (CT), many millimetric nodule images with bilateral and diffuse spread were identified. A pleural effusion reaching 1.5 $\mathrm{cm}$ in diameter was observed in the left pleural leaf (Figure 2), and a suspicious mass image was noted in the left peribronchial/paravertebral area, adjacent to the pleura, measuring $6 \times 3.7 \mathrm{~cm}$.

The patient's sputum was three-times negative for Acidresistant bacillus (ARB). There was no growth in a sputum culture, and the sputum cytology was not diagnostic. Positron Emission Tomography (PET CT) was requested due to the suspicious mass. A primary malignant mass in the left lung was considered compatible with millimetric metastatic nodules in the bilateral lungs and mediastinal lymph nodes, as well as surrenal and bone metastases (Figure 3).

A video bronchoscopic examination revealed an allaround narrowing and train rail view in the left lower lobe bronchus, where a bronchial lavage and punch biopsy were performed (Figure 4), the histopathological examination of which revealed adenocarcinoma (consistent with the papillary variant).

The patient was referred to the oncology clinic with a diagnosis of Stage 4 non-small-cell lung cancer.

\section{DISCUSSION}

Radiologically, miliary lesion diseases are pulmonary sarcoidosis, miliary tuberculosis, lymphoma, pulmonary alveolar microlithiasis, pulmonary histoplasmosis, metastatic lung cancers, talc granulomatosis, early stage of pneumoconiosis and pulmonary hemosiderosis. Miliary metastases of primary lung cancers are very rare (5).

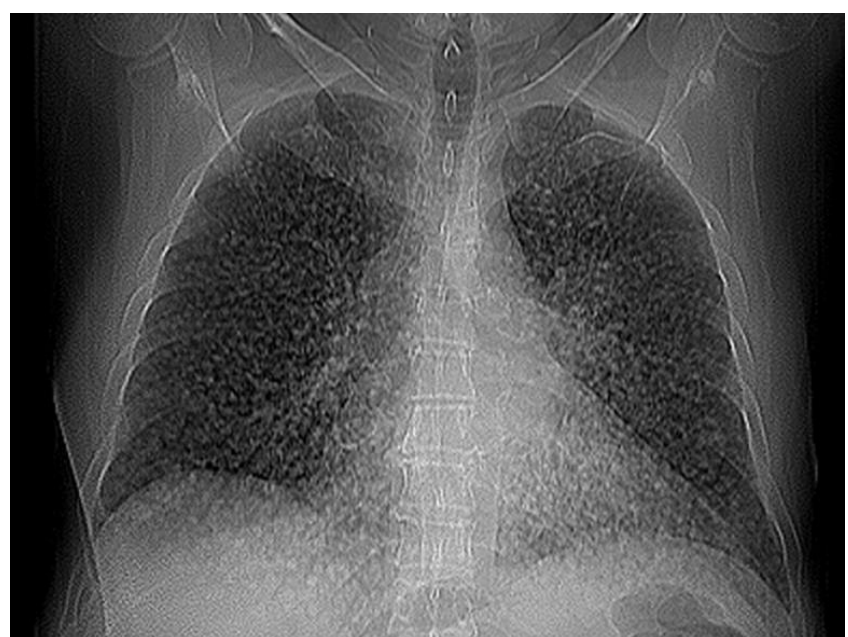

Figure 1: Diffuse miliary lesions on chest $X$-ray

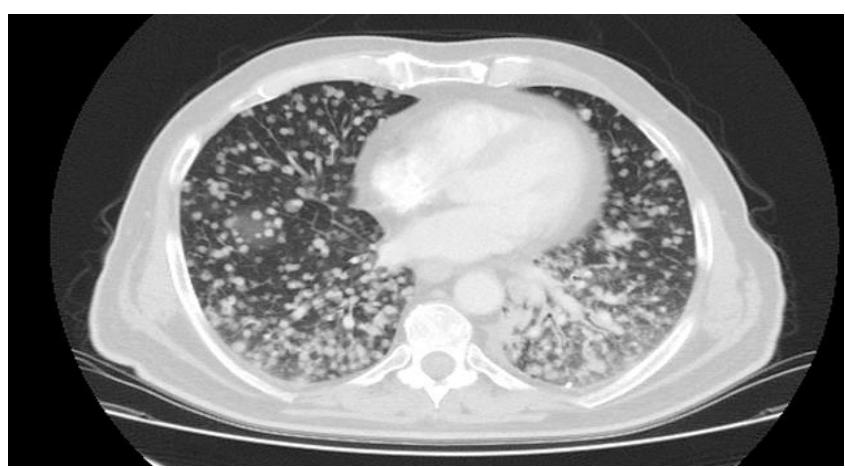

Figure 2: Thorax computed tomography 


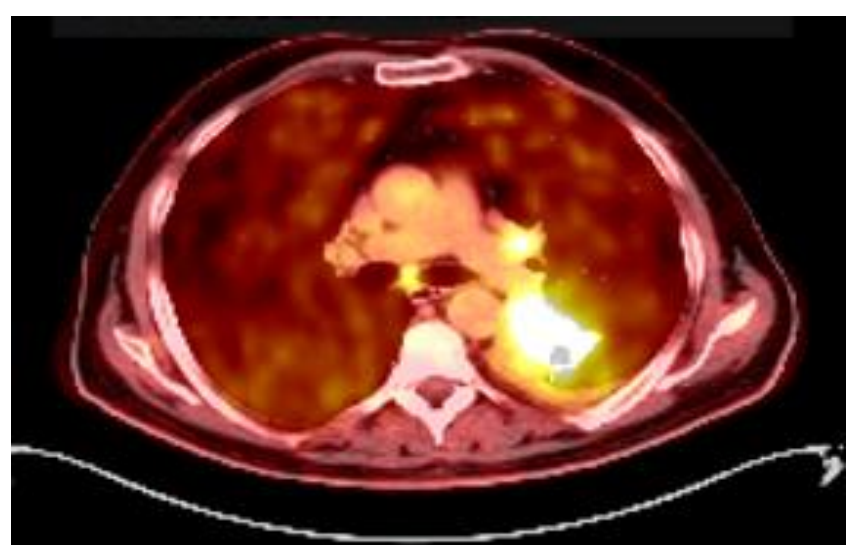

Figure 3: Mass and diffuse involvement in the parenchyma on positron emission tomography

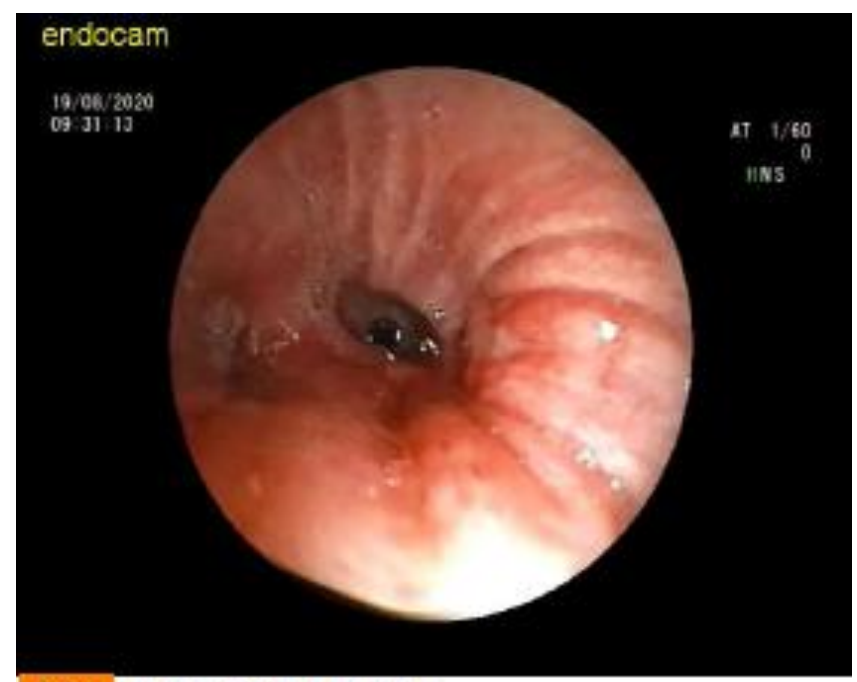

\section{Sol alt lob bronșu}

Figure 4: Video bronchoscopic view of the left lower lobe bronchus

The presence of accompanying lymphadenopathies and pleural effusion in a patient with miliary shadowing in the lungs should suggest that the nodules may be due to malignancy (4). Lung metastases can manifest as multiple pulmonary nodules, pleural effusions and enlargements of the lymph nodes on chest $\mathrm{X}$-ray. In rare cases, however, metastases in lung cancers can be seen as diffuse micronodules, the largest of which is $5 \mathrm{~mm}$, which is referred to as miliary spread. A miliary appearance indicates hematogenous spread, with the most common primary lung cancer with a miliary appearance in the lungs being adenocarcinoma (6).

The diagnosis of miliary adenocarcinoma is often difficult, and any such diagnosis should be confirmed histopathologically (7). In the present case, the histological diagnosis was lung adenocarcinoma, based on a bronchoscopic punch biopsy and bronchial lavage.
A miliary appearance in the lungs can be seen in many diseases, and Thorax CT and PET scans will help in the differential diagnosis. Pulmonary adenocarcinoma should be considered in cases presenting with miliary shadowing.

\section{CONFLICTS OF INTEREST}

None declared.

\section{AUTHOR CONTRIBUTIONS}

Concept - C.T., Y.A.; Planning and Design - C.T., Y.A.; Supervision - C.T., Y.A.; Funding -; Materials -; Data Collection and/or Processing -; Analysis and/or Interpretation -; Literature Review - C.T.; Writing - C.T., Y.A.; Critical Review - Y.A.

\section{YAZAR KATKILARI}

Fikir - C.T., Y.A.; Tasarım ve Dizayn - C.T., Y.A.; Denetleme - C.T., Y.A.; Kaynaklar -; Malzemeler -; Veri Toplama ve/veya İşleme -.; Analiz ve/veya Yorum -; Literatür Taraması - C.T.; Yazıyı Yazan - C.T., Y.A.; Eleştirel İnceleme - Y.A.

\section{REFERENCES}

1. Siegel RL, Miller KD, Jemal A. Cancer Statistics, 2015.CA Cancer J Clin 2015; 65:5-29. [CrossRef]

2. Akman C. Akciğer Kanserlerinde Radyolojik Bulgular. İ.Ü. Cerrahpaşa Tıp Fakültesi Sürekli Tıp eğitimi Etkinlikleri Sempozyumu Dizisi No:58.Kasım 2007;129-32.

3. Buccheri G, Barberis P, Delfino MS. Diagnostic, morphologic, and histopathologic correlates in bronchogenic carcinoma. A reviev of 1,045 bronchoscopic examinations. Chest. 1991; 99:809-14. [CrossRef]

4. Uzer F, Coşkun HŞ, Çilli A. Miliyer görünüm ile başvuran akciğer adenokarsinomu. Respir Case Rep 2017; 6:1147. [CrossRef]

5. Kim CS, Lee KN, Lee JH. Comparison of high resolution $\mathrm{CT}$ findings between miliary metastases and miliary tuberculosis. J Korean Radial Soc 2003; 48:147-52. [CrossRef]

6. Kobayashi M, Takeuchi T, Bandobashi K, Uemura $Y$, Ogawa $Y, O h t s u k i$, et al. Diffuse micronoduler pulmonary metastasis of lung adenocarcinoma predicts gefitinib response in association with epidermal growth factor receptor mutations. Anticancer Res 2006; 26:1621-6. 